\title{
Aplikasi Bakteri dalam Perlakuan Seed Coating untuk Mempertahankan Viabilitas dari Benih Cabai (Capsicum annuum L.) yang Sehat
}

\section{Bacteria Application in Seed Coating Treatment for Maintaining the Viability of Undiseased Chilli Seed (Capsicum annuum L.)}

\section{Herliyana Indahwardani, Eny Widajati", dan Giyanto}

Departemen Agronomi dan Hortikultura, Fakultas Pertanian, Institut Pertanian Bogor (Bogor Agricultural University), Jl. Meranti, Kampus IPB Darmaga, Bogor 16680, Indonesia Telp.\&Faks.62-251-8629353 e-mail agronipb@indo.net.id

"Penulis untuk korespondensi : enywidajati@yahoo.co.id

Disetujui 16 Januari 2017 / Published Online 24 Januari 2017

\begin{abstract}
This research was conducted to study the effect of seed coating using Bacillus subtilis, Pseudomonas group fluorescens and Serratia marcescens toward the viability of chilli seed (Capsicum annuum L.) during storage. This study used nested design with three replications. The main plot is storage period $(0,3,6,9,12$, $15,18,21$ and 24 weeks) and the subplot is seed coating treatment with bacteria (Bacillus subtilis, Pseudomonas group fluorescens, Serratia marcescens and control). Chilli seed IPB C5 still have a good viability until the end of storage, showed from the percentage of germination that is $77.33 \%$. Control and coating used bacteria treatment showed unsignificant difference on germination, vigour index, growth rate and normal seedling dry weight. The bacteria as coater were still alive until 24 weeks of storage periode with populations $5.89 \times 10^{4} \mathrm{cfu} \mathrm{g}^{-1}$ for Pseudomonas group fluorescens, $4.79 \times 10^{4} \mathrm{cfu}^{-1}$ for Bacillus subtilis and $1.70 \times 10^{4} \mathrm{cfu}^{-1}$ for Serratia marcescens.
\end{abstract}

Keywords: chilli seed, plant growth promoting rhizobacteria, seed coating, storage period, viability

\section{ABSTRAK}

Penelitian ini bertujuan mengetahui pengaruh perlakuan pelapisan benih menggunakan bakteri Bacillus subtilis, Pseudomonas keompok. fluorescens dan Serratia marcescens terhadap viabilitas benih cabai (Capsicum annuum L.) selama di penyimpanan. Penelitian ini mengunakan rancangan petak tersarang dengan tiga ulangan. Petak utama adalah periode simpan $(0,3,6,9,12,15,18,21$ dan 24 minggu) dan anak petak adalah perlakuan coating dengan bakteri tertentu (Bacillus subtilis, Pseduomonas kelompok fluorescens, Serratia marcescen dan kontrol). Benih cabai IPB C5 masih memiliki viabilitas yang cukup baik hingga akhir penyimpanan, ditunjukkan dengan nilai daya berkecambah sebesar $77.33 \%$. Perlakuan kontrol dan coating menggunakan bakteri menunjukkan nilai daya berkecambah, indeks vigor, kecepatan tumbuh dan bobot kering kecambah normal yang tidak berbeda nyata. Ketiga bakteri yang digunakan sebagai pelapis masih dapat hidup sampai periode simpan 24 minggu dengan populasi $5.89 \times 10^{4}$ cfu $g^{-1}$ untuk Pseudomonas kelompok fluorescens, $4.79 \times 10^{4} \mathrm{cfu} \mathrm{g}^{-1}$ untuk Bacillus subtilis dan $1.70 \times 10^{4} \mathrm{cfu}$ $g^{-1}$ untuk Serratia marcescens.

Kata kunci: bakteri pemacu pertumbuhan tanaman, benih cabai, pelapisan benih, periode simpan, viabilitas 


\section{PENDAHULUAN}

Produksi cabai di Indonesia sangat dominan dibandingkan dengan produksi sayuran yang lainnya karena permintaannya yang terus meningkat dan daya adaptasinya yang tinggi. Menurut data dari Badan Pusat Statistik (2012), produksi cabai dari tahun 2003 sampai tahun 2010 mengalami fluktuasi namun tidak terlalu signifikan dan pada tahun 2011 mencapai produksi nasional tertinggi yaitu 1.9 juta ton diikuti produksi kubis, kentang, bawang merah dan tomat. Produktivitas nasional cabai masih tergolong rendah yaitu 6.19 ton $\mathrm{ha}^{-1}$ pada tahun 2011, namun untuk wilayah regional, produktivitas cabai di Jawa Barat menempati urutan tertinggi yaitu 12.5 ton $\mathrm{ha}^{-1}$ (BPS 2012).

Produktivitas nasional yang rendah disebabkan budi daya tanaman cabai di Indonesia hingga saat ini masih mengalami beberapa kendala. Kendala tersebut berkaitan dengan produksi dan kualitas benih, teknik budidaya, serangan hama dan penyakit serta sulitnya memperoleh varietas unggul berdaya hasil tinggi karena harga benihnya yang mahal. Maka dari itu diperlukan penanganan budi daya dan produksi benih yang tepat. Benih yang baik atau bermutu diperlukan untuk mendapatkan pertumbuhan tanaman cabai yang baik (Sumarni 1996). Mutu benih terdiri atas mutu fisiologis, genetis dan patologis yang dapat mengalami penurunan selama benih disimpan. Mutu benih selama penyimpanan dapat dipertahankan atau ditingkatkan dengan berbagai cara salah satunya dengan perlakuan benih.

Perlakuan benih umumnya diaplikasikan untuk mempercepat perkecambahan benih maupun mencegah penyakit yang dapat menyerang tanaman cabai atau mengendalikan penyakit yang sudah berada di dalam benih cabai. Menurut Rubatzky dan Yamaguchi (1999), penyakit yang spesifik menyerang cabai antara lain Antraknosa, bercak daun bakteri dan layu Fusarium. Perlakuan benih untuk mengendalikan berbagai penyakit tersebut umumnya dilakukan dengan perendaman benih. Benih direndam dalam air panas pada suhu $55^{\circ} \mathrm{C}$ selama 30 menit atau direndam pada larutan fungisida sistemik golongan Triazole atau Pyrimidin untuk mengendalikan penyakit Antraknosa (Suryaningsih et al. 1996). Mutu patologis benih perlu diperhatikan karena secara langsung mampu mempengaruhi mutu fisiologis benih yaitu viabilitas benih akan tetapi, pengendalian penyakit tersebut umumnya dilakukan menggunakan bahan kimia yang dapat berdampak buruk pada lingkungan.
Perkembangan ilmu hayati dan pertanian yang cukup pesat berpengaruh terhadap terciptanya teknologi pengembangan pertanian dengan memanfaatkan agen hayati, seperti bakteri (Plant Growth Promoting Rhizobacteria/PGPR). Dalam beberapa penelitian, bakteri spesies tertentu dapat meningkatkan pertumbuhan tanaman serta mengendalikan penyakit tertentu dengan memproduksi hormon pertumbuhan tanaman dan senyawa metabolit lainnya. Berdasarkan penelitian Iswati (2012), PGPR berperan dalam mempengaruhi pertumbuhan tanaman tomat terutama dalam memacu pertumbuhan batang, daun maupun akar. Perlakuan benih dengan berbagai isolat rhizobakteri (Bacillus sp., Pseudomonas sp. dan Serratia sp.) memberikan dampak positif terhadap perkecambahan benih dan pertumbuhan bibit cabai (Sutariati et al. 2006b) serta mampu menghambat pertumbuhan koloni Colletotrichum capsici (Sutariati et al. 2006a). Pelapisan benih menggunakan tiga jenis bakteri yaitu Bacillus subtilis (EKK10), Pseudomonas kelompok fluorescens (P24) dan Serratia marcescens (AR1) diharapkan mampu mempertahankan dan meningkatkan viabilitas benih cabai selama di penyimpanan.

\section{METODE PENELITIAN}

Penelitian ini dilaksanakan di Laboratorium Ilmu Teknologi Benih dan Laboratorium Bakteriologi Tumbuhan, Fakultas Pertanian, IPB Darmaga. Penelitian dilaksanakan pada bulan Oktober 2012 sampai bulan April 2013. Bahan yang digunakan dalam penelitian ini adalah benih cabai besar genotipe IPB C5, suspensi isolat bakteri Bacillus subtillis (EKK10), Pseudomonas kel. fluorescens (P24) dan Serratia marcescens (AR1), Natrium Alginat (perekat coating), media Tryptic Soy Agar (TSA), media King's B 50\%, dan media Nutrient Agar (NA).

Penelitian ini menggunakan rancangan petak tersarang (nested design). Petak utama adalah periode simpan dan anak petak adalah perlakuan coating dengan bakteri tertentu. Periode simpan mulai $0,3,6,9,12,15,18,21$ dan 24 minggu. Sedangkan untuk anak petak yaitu perlakuan seed coating meliputi $\mathrm{C}_{0}$ (kontrol /tanpa perlakuan seed coating), $\mathrm{C}_{\mathrm{B}} \quad$ (coating menggunakan bakteri Bacillus subtilis), $\mathrm{C}_{\mathrm{P}}$ (coating menggunakan bakteri Pseudomonas kel. fluorescens), dan $\mathrm{C}_{\mathrm{S}}$ (coating menggunakan bakteri Serratia marcescens). Penelitian dilakukan menggunakan tiga ulangan.

Analisis ragam terhadap data hasil pengamatan akan dilakukan dengan uji F, apabila 
menunjukkan pengaruh nyata maka akan dilakukan uji lanjut Duncan Multiple Range Test (DMRT) pada taraf 5\%.

Pelapisan benih (seed coating) dilakukan dengan mesin coating milik P.T. East West Seed Indonesia, Purwakarta. Volume suspensi bakteri untuk melapisi benih cabai adalah $20 \mathrm{ml}$ untuk setiap $100 \mathrm{~g}$ benih. Perekat yang digunakan adalah Natrium Alginat sebanyak $5 \mathrm{~g}$ untuk setiap $100 \mathrm{ml}$ isolat. Benih yang telah dilapisi kemudian dikeringkan sampai benih memiliki kadar air yang aman untuk disimpan yaitu sekitar $6 \%$. Benih dikemas dalam wadah plastik klip dengan berat benih satu kemasan sekitar 3.9 gram. Benih yang telah dikemas dimasukkan ke dalam stoples yang di dalamnya telah diberi silica gel. Benih dengan perlakuan tertentu disimpan di dalam stoples yang berbeda. Kegiatan penyimpanan dilaksanakan di dalam ruangan dengan suhu kamar $\left( \pm 27{ }^{\circ} \mathrm{C}\right)$ selama 24 minggu.

Pengujian viabilitas benih dilakukan setiap 3 minggu menggunakan metode uji di atas kertas (UDK) pada alat pengecambah benih IPB 73-2AB. Parameter yang diamati meliputi: (1) kadar air benih, (2) daya berkecambah benih, (3) indeks vigor, (4) kecepatan tumbuh, (5) bobot kering kecambah normal dan (6) populasi/kerapatan bakteri.

\section{HASIL DAN PEMBAHASAN}

Perlakuan seed coating dan periode simpan serta interaksinya memberikan pengaruh yang sangat nyata terhadap kadar air benih selama di penyimpanan. Nilai tengah kadar air perlakuan benih yang diberi perlakuan coating menggunakan bakteri lebih rendah dibandingkan perlakuan benih tanpa coating atau kontrol (Tabel 1). Rendahnya nilai kadar air perlakuan coating diduga karena pelapisan benih mampu melindungi benih dari pengaruh kelembaban ruang simpan, seperti pada benih buncis perlakuan tanpa pelapis (kontrol) yang memiliki kadar air lebih tinggi dibandingkan dengan benih yang mendapatkan perlakuan pelapisan menggunakan Methylobacterium spp. (Yuningsih 2009).

Kadar air benih terus mengalami penurunan hingga akhir penyimpanan walaupun disimpan dalam plastik polietilen. Hal ini disebabkan oleh pemberian silica gel pada wadah simpan. Berdasarkan persentase $\mathrm{RH}$ dan suhu yang diamati menggunakan hygrothermometer, RH pada wadah simpan yang berisi silica gel berkisar antara 14 hingga $45 \%$ dengan suhu 27 $28.7{ }^{\circ} \mathrm{C}$. Benih cabai termasuk ke dalam jenis benih ortodoks sehingga kesetimbangan kadar air benih tetap rendah perlu dipertahankan selama penyimpanan. Menurut Copeland and McDonald (2001), kadar air benih tidak boleh melebihi $14 \%$ maupun di bawah 5\%. Penyimpanan benih pada kadar air benih di atas $14 \%$ dapat memacu dan meningkatkan respirasi, panas dan serangan cendawan yang dapat menurunkan viabilitas benih secara cepat sedangkan kadar air benih di bawah 5\% dapat menyebabkan kerusakan pada struktur membran benih.

Tabel 1. Pengaruh interaksi antara perlakuan pelapisan benih dan periode simpan terhadap kadar air benih

\begin{tabular}{ccccc}
\hline \multirow{2}{*}{ PS (minggu) } & \multicolumn{4}{c}{ Kadar air } \\
\cline { 2 - 5 } & Tanpa coating & B. subtilis & P. kelompok fluorescens & S. marcescens \\
\hline 0 & $10.0 \mathrm{ab}$ & $4.8 \mathrm{c}-\mathrm{h}$ & $4.4 \mathrm{~d}-\mathrm{h}$ & $6.8 \mathrm{c}-\mathrm{e}$ \\
3 & $10.7 \mathrm{a}$ & $4.2 \mathrm{~d}-\mathrm{h}$ & $4.5 \mathrm{~d}-\mathrm{h}$ & $4.3 \mathrm{~d}-\mathrm{h}$ \\
6 & $6.5 \mathrm{~cd}$ & $5.1 \mathrm{c}-\mathrm{g}$ & $5.0 \mathrm{c}-\mathrm{h}$ & $4.4 \mathrm{~d}-\mathrm{h}$ \\
9 & $7.9 \mathrm{bc}$ & $3.0 \mathrm{f}-\mathrm{h}$ & $3.8 \mathrm{e}-\mathrm{h}$ & $3.0 \mathrm{f}-\mathrm{h}$ \\
12 & $5.3 \mathrm{c}-\mathrm{f}$ & $4.7 \mathrm{c}-\mathrm{h}$ & $4.0 \mathrm{~d}-\mathrm{h}$ & $3.5 \mathrm{f}-\mathrm{h}$ \\
15 & $3.8 \mathrm{~d}-\mathrm{h}$ & $3.2 \mathrm{f}-\mathrm{h}$ & $2.7 \mathrm{gh}$ & $2.5 \mathrm{~h}$ \\
18 & $4.1 \mathrm{~d}-\mathrm{h}$ & $2.9 \mathrm{f}-\mathrm{h}$ & $4.1 \mathrm{~d}-\mathrm{h}$ & $3.7 \mathrm{e}-\mathrm{h}$ \\
21 & $4.1 \mathrm{~d}-\mathrm{h}$ & $3.2 \mathrm{f}-\mathrm{h}$ & $3.3 \mathrm{f}-\mathrm{h}$ & $3.3 \mathrm{f}-\mathrm{h}$ \\
24 & $4.4 \mathrm{~d}-\mathrm{h}$ & $3.7 \mathrm{~d}-\mathrm{h}$ & $3.7 \mathrm{e}-\mathrm{h}$ & $3.2 \mathrm{f}-\mathrm{h}$ \\
\hline
\end{tabular}

Keterangan : Angka yang diikuti huruf yang sama menunjukkan hasil yang tidak berbeda nyata menurut uji DMRT 5\%.

Interaksi antara perlakuan seed coating dengan periode simpan menunjukkan pengaruh yang nyata pada parameter pengamatan daya berkecambah benih (Tabel 2). Daya berkecambah benih hanya dipengaruhi oleh faktor tunggal periode simpan, sedangkan faktor tunggal pelapisan benih memberikan pengaruh yang sama pada seluruh perlakuan. Persentase daya 
berkecambah benih sampai periode simpan 24 minggu masih dapat dipertahankan tinggi yaitu $71.3-81.3 \%$ serta tidak berbeda nyata dengan persentase daya berkecambah pada periode simpan 0 minggu.

Tabel 2. Pengaruh interaksi antara perlakuan pelapisan benih dan periode simpan terhadap daya berkecambah benih

\begin{tabular}{ccccc}
\hline \multirow{2}{*}{ PS (minggu) } & \multicolumn{3}{c}{ Daya berkecambah } \\
\cline { 2 - 5 } & Tanpa coating & B. subtilis & P. kelompok fluorescens & S. marcescens \\
\hline 0 & $88.7 \mathrm{ab}$ & $81.3 \mathrm{a}-\mathrm{f}$ & $92.0 \mathrm{a}$ & $68.0 \mathrm{ef}$ \\
3 & $82.7 \mathrm{a}-\mathrm{f}$ & $79.3 \mathrm{a}-\mathrm{f}$ & $81.3 \mathrm{a}-\mathrm{f}$ & $86.7 \mathrm{a}-\mathrm{c}$ \\
6 & $80.7 \mathrm{a}-\mathrm{f}$ & $80.7 \mathrm{a}-\mathrm{f}$ & $82.0 \mathrm{a}-\mathrm{f}$ & $81.3 \mathrm{a}-\mathrm{f}$ \\
9 & $88.7 \mathrm{ab}$ & $75.3 \mathrm{~b}-\mathrm{f}$ & $85.3 \mathrm{a}-\mathrm{d}$ & $87.3 \mathrm{a}-\mathrm{c}$ \\
12 & $87.3 \mathrm{a}-\mathrm{c}$ & $82.7 \mathrm{a}-\mathrm{f}$ & $74.7 \mathrm{~b}-\mathrm{f}$ & $84.7 \mathrm{a}-\mathrm{d}$ \\
15 & $66.7 \mathrm{f}$ & $78.7 \mathrm{a}-\mathrm{f}$ & $69.3 \mathrm{~d}-\mathrm{f}$ & $72.0 \mathrm{c}-\mathrm{f}$ \\
18 & $86.0 \mathrm{a}-\mathrm{c}$ & $80.0 \mathrm{a}-\mathrm{f}$ & $78.0 \mathrm{a}-\mathrm{f}$ & $82.0 \mathrm{a}-\mathrm{f}$ \\
21 & $81.3 \mathrm{a}-\mathrm{f}$ & $89.3 \mathrm{ab}$ & $84.0 \mathrm{a}-\mathrm{e}$ & $85.3 \mathrm{a}-\mathrm{d}$ \\
24 & $81.3 \mathrm{a}-\mathrm{f}$ & $76.7 \mathrm{a}-\mathrm{f}$ & $71.3 \mathrm{c}-\mathrm{f}$ & $80.0 \mathrm{a}-\mathrm{f}$ \\
\hline
\end{tabular}

Keterangan : Angka yang diikuti huruf yang sama menunjukkan hasil yang tidak berbeda nyata menurut uji DMRT 5\%

Interaksi antara perlakuan seed coating dengan periode simpan menunjukkan pengaruh yang sangat nyata terhadap parameter pengamatan indeks vigor (Tabel 3). Indeks vigor yang dimiliki benih cabai masih cukup baik hingga periode simpan 24 minggu. Pada perlakuan coating menggunakan bakteri, indeks vigor meningkat pada periode simpan 6 minggu dan selanjutnya terus mengalami fluktuasi hingga periode simpan
24 minggu akan tetapi rata-rata nilai indeks vigor periode simpan 0 minggu dan periode simpan 24 minggu tidak berbeda nyata. Indeks vigor pada perlakuan tanpa pelapisan (kontrol) tidak berbeda nyata dengan indeks vigor pada perlakuan pelapisan menggunakan $S$. marcescens dan nilai indeks vigor kedua perlakuan tersebut masih tinggi pada periode simpan 24 minggu.

Tabel 3. Pengaruh interaksi antara perlakuan seed coating dan periode simpan terhadap indeks vigor benih

\begin{tabular}{ccccc}
\hline \multirow{2}{*}{ PS (minggu) } & \multicolumn{5}{c}{ Indeks vigor } \\
\cline { 2 - 5 } & Tanpa coating & B. subtilis & P. kelompok fluorescens & S. marcescens \\
\hline 0 & $38.0 \mathrm{a}-\mathrm{g}$ & $22.7 \mathrm{f}-\mathrm{j}$ & $18.7 \mathrm{ij}$ & \\
3 & $24.7 \mathrm{~d}-\mathrm{j}$ & $20.0 \mathrm{~h}-\mathrm{j}$ & $17.3 \mathrm{j}$ & $20.0 \mathrm{~h}-\mathrm{j}$ \\
6 & $40.0 \mathrm{a}-\mathrm{f}$ & $30.0 \mathrm{c}-\mathrm{j}$ & $36.7 \mathrm{~b}-\mathrm{h}$ & $28.0 \mathrm{c}-\mathrm{j}$ \\
9 & $56.7 \mathrm{a}$ & $28.0 \mathrm{c}-\mathrm{j}$ & $40.0 \mathrm{a}-\mathrm{f}$ & $42.7 \mathrm{a}-\mathrm{e}$ \\
12 & $38.7 \mathrm{a}-\mathrm{g}$ & $27.3 \mathrm{c}-\mathrm{j}$ & $26.7 \mathrm{c}-\mathrm{j}$ & $56.0 \mathrm{a}$ \\
15 & $40.0 \mathrm{a}-\mathrm{f}$ & $42.7 \mathrm{a}-\mathrm{d}$ & $33.3 \mathrm{~b}-\mathrm{j}$ & $36.7 \mathrm{~b}-\mathrm{h}$ \\
18 & $49.3 \mathrm{ab}$ & $48.7 \mathrm{ab}$ & $40.7 \mathrm{a}-\mathrm{e}$ & $40.7 \mathrm{a}-\mathrm{e}$ \\
21 & $21.3 \mathrm{~g}-\mathrm{j}$ & $44.0 \mathrm{a}-\mathrm{c}$ & $30.7 \mathrm{~b}-\mathrm{j}$ & $40.0 \mathrm{a}-\mathrm{f}$ \\
24 & $44.0 \mathrm{a}-\mathrm{c}$ & $32.7 \mathrm{~b}-\mathrm{j}$ & $19.3 \mathrm{ij}$ & $36.0 \mathrm{~b}-\mathrm{i}$ \\
\hline
\end{tabular}

Keterangan : Angka yang diikuti huruf yang sama menunjukkan hasil yang tidak berbeda nyata menurut uji DMRT 5\%.

Perlakuan tanpa coating (kontrol) memiliki nilai yang paling baik pada seluruh parameter pengamatan, yaitu kadar air, daya berkecambah, indeks vigor, kecepatan tumbuh dan bobot kering kecambah normal. Walaupun demikian, perlakuan seed coating menggunakan Bacillus subtilis (EKK10), Pseudomonas kelompok fluorescens (P24) dan Serratia 
marcescens (AR1) juga masih menunjukkan hasil yang baik pada seluruh parameter pengamatan ditunjukkan dengan pertumbuhan dan viabilitasnya yang tidak jauh berbeda dibandingkan perlakuan tanpa coating.

Berdasarkan hasil penelitian Sutariati et al. (2006b), dibandingkan dengan tanpa perlakuan sebagai standar, perlakuan benih dengan rhizobakteri nyata meningkatkan daya berkecambah, potensi tumbuh maksimum, indeks vigor dan kecepatan tumbuh relatif serta menurunkan $\mathrm{T}_{50}$ benih cabai yang diuji. Sutariati dan Wahab (2012) juga menyatakan bahwa perlakuan benih dengan rhizobakteri Bacillus spp., P. fluorescens dan Serratia sp. mampu meningkatkan potensi tumbuh maksimum, keserempakan tumbuh, bobot kering kecambah normal dan laju pertumbuhan kecambah benih cabai secara signifikan terhadap kontrol. Hasil penelitian lain menyatakan bahwa peningkatan DB dipengaruhi oleh matriconditioning dan peran B. subtilis 5/B. perlakuan B. subtilis. 5/B dan matriconditioning $+B$. subtilis $5 / \mathrm{B}$ pada dua tingkat vigor benih padi mempunyai nilai DB yang lebih tinggi (91\% dan 99.5\%) dibandingkan perlakuan benih lainnya (Yukti 2009). Perlakuan agens hayati (Pseudomonas spp. dan B. subtilis) dengan atau tanpa matriconditioning dapat memperbaiki daya berkecambah, indeks vigor, bobot kering kecambah normal, kecepatan tumbuh, potensi tumbuh maksimum dan $\mathrm{T}_{50}$ dibandingkan dengan benih yang tidak diberi perlakuan (Agustiansyah 2011).

Perlakuan seed coating dan periode simpan berpengaruh sangat nyata terhadap parameter pengamatan $\mathrm{K}_{\mathrm{CT}}$ (Tabel 4). Nilai $\mathrm{K}_{\mathrm{CT}}$ masih dapat dipertahankan tinggi sampai periode simpan 24 minggu karena nilainya yang tidak berbeda nyata dengan nilai $\mathrm{K}_{\mathrm{CT}}$ pada periode simpan 0 minggu. Nilai $K_{\mathrm{CT}}$ perlakuan kontrol lebih tinggi dibandingkan perlakuan pelapisan benih menggunakan bakteri walaupun tidak berbeda nyata dengan perlakuan pelapisan menggunakan Pseudomonas kelompok fluorescens.

Tabel 4. Pengaruh interaksi antara perlakuan pelapisan benih dan periode simpan terhadap kecepatan tumbuh benih

\begin{tabular}{|c|c|c|c|c|}
\hline \multirow{2}{*}{ PS (minggu) } & \multicolumn{4}{|c|}{ Kecepatan tumbuh } \\
\hline & Tanpa coating & B. subtilis & $P$. kelompok fluorescens & S. marcescens \\
\hline \multicolumn{5}{|c|}{ 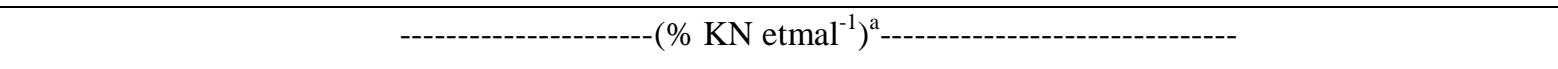 } \\
\hline 0 & $9.7 \mathrm{~g}-\mathrm{j}$ & $10.0 \mathrm{e}-\mathrm{j}$ & $11.1 \mathrm{~b}-\mathrm{h}$ & $8.4 \mathrm{j}$ \\
\hline 3 & $10.5 \mathrm{c}-\mathrm{i}$ & $9.8 \mathrm{f}-\mathrm{j}$ & $9.7 \mathrm{~g}-\mathrm{j}$ & $9.4 \mathrm{~h}-\mathrm{j}$ \\
\hline 6 & $11.4 \mathrm{a}-\mathrm{h}$ & 11.9 a-e & $11.3 \mathrm{a}-\mathrm{h}$ & $12.4 \mathrm{a}-\mathrm{c}$ \\
\hline 9 & $12.6 \mathrm{ab}$ & $11.0 \mathrm{~b}-\mathrm{h}$ & 11.9 a-e & $12.2 \mathrm{a}-\mathrm{d}$ \\
\hline 12 & $10.6 \mathrm{c}-\mathrm{i}$ & $9.8 \mathrm{f}-\mathrm{j}$ & $11.3 \mathrm{a}-\mathrm{h}$ & $8.7 \mathrm{ij}$ \\
\hline 15 & $12.1 \mathrm{a}-\mathrm{d}$ & $10.3 \mathrm{~d}-\mathrm{i}$ & $11.6 \mathrm{a}-\mathrm{g}$ & $11.6 \mathrm{a}-\mathrm{g}$ \\
\hline 18 & $13.2 \mathrm{a}$ & $10.5 \mathrm{c}-\mathrm{i}$ & $10.0 \mathrm{e}-\mathrm{j}$ & $10.4 \mathrm{c}-\mathrm{i}$ \\
\hline 21 & $12.3 \mathrm{a}-\mathrm{d}$ & $10.9 \mathrm{~b}-\mathrm{h}$ & $10.9 \mathrm{~b}-\mathrm{h}$ & $10.7 \mathrm{~b}-\mathrm{h}$ \\
\hline 24 & $11.8 \mathrm{a}-\mathrm{f}$ & $9.7 \mathrm{~g}-\mathrm{j}$ & $9.8 \mathrm{f}-\mathrm{j}$ & $9.7 \mathrm{~g}-\mathrm{j}$ \\
\hline
\end{tabular}

Keterangan : Angka yang diikuti huruf yang sama menunjukkan hasil yang tidak berbeda nyata menurut uji DMRT 5\%.

Berdasarkan parameter pengamatan bobot kering kecambah normal, perlakuan seed coating dan periode simpan berpengaruh sangat nyata. Perlakuan benih tanpa coating (kontrol) memiliki nilai rataan yang lebih tinggi dibandingkan perlakuan benih dengan coating bakteri. Pada beberapa periode simpan, BKKN perlakuan kontrol tidak berbeda nyata dengan perlakuan coating menggunakan bakteri, yaitu pada periode simpan 6-15 minggu. Pada periode simpan 18 minggu, nilai BKKN kontrol mengalami peningkatan sedangkan nilai BKKN perlakuan coating menggunakan bakteri mengalami penurunan (Tabel 5). Perlakuan kontrol tetap memiliki nilai BKKN yang paling tinggi dibandingkan perlakuan lain hingga periode simpan 24 minggu. 
Tabel 5. Pengaruh interaksi antara perlakuan pelapisan benih dan periode simpan terhadap bobot kering kecambah normal

\begin{tabular}{|c|c|c|c|c|}
\hline \multirow{2}{*}{ PS (minggu) } & \multicolumn{4}{|c|}{ Bobot kering kecambah normal } \\
\hline & Tanpa coating & B. subtilis & $P$. kelompok fluorescens & S. marcescens \\
\hline \multicolumn{5}{|c|}{ - } \\
\hline 0 & $48.1 \mathrm{f}$ & $55.7 \mathrm{f}$ & $50.3 \mathrm{f}$ & $75.5 \mathrm{de}$ \\
\hline 3 & $81.5 \mathrm{a}-\mathrm{e}$ & $45.6 \mathrm{f}$ & $76.2 \mathrm{c}-\mathrm{e}$ & 83.8 a-e \\
\hline 6 & 90.9 a-e & $88.1 \mathrm{a}-\mathrm{e}$ & 89.7 a-e & 83.2 a-e \\
\hline 9 & 86.9 a-e & 84.9 a-e & 88.8 a-e & $91.2 \mathrm{a}-\mathrm{d}$ \\
\hline 12 & $93.5 \mathrm{a}-\mathrm{c}$ & 77.9 b-e & 82.5 a-e & 89.1 a-e \\
\hline 15 & $81.8 \mathrm{a}-\mathrm{e}$ & $77.4 \mathrm{~b}-\mathrm{e}$ & 80.3 a-e & 85.9 a-e \\
\hline 18 & $94.2 \mathrm{ab}$ & $73.6 \mathrm{e}$ & $73.8 \mathrm{de}$ & $78.5 \mathrm{~b}-\mathrm{e}$ \\
\hline 21 & $94.7 \mathrm{ab}$ & $82.1 \mathrm{a}-\mathrm{e}$ & 86.5 a-e & 88.8 a-e \\
\hline 24 & $97.2 \mathrm{a}$ & $81.7 \mathrm{a}-\mathrm{e}$ & 82.0 a-e & $81.6 \mathrm{a}-\mathrm{e}$ \\
\hline
\end{tabular}

Keterangan : Angka yang diikuti huruf yang sama menunjukkan hasil yang tidak berbeda nyata menurut uji DMRT 5\%.

Perlakuan periode simpan memberikan pengaruh yang nyata terhadap populasi bakteri. Bakteri yang hidup di permukaan kulit benih terus menurun hingga periode simpan 24 minggu (Tabel 6). Perlakuan seed coating berpengaruh sangat nyata terhadap populasi bakteri. Populasi Pseudomonas kelompok fluorescens yang hidup pada permukaan benih memiliki nilai yang paling tinggi dibandingkan dua bakteri lainnya pada setiap periode simpan walaupun tidak berbeda nyata sehingga ketiga jenis bakteri tersebut memiliki kemampuan yang sama sampai periode simpan 24 minggu.

Tabel 6. Pengaruh interaksi antara perlakuan pelapisan benih dan periode simpan terhadap populasi bakteri pada permukaan benih

\begin{tabular}{|c|c|c|c|}
\hline \multirow{2}{*}{ PS (minggu) } & \multicolumn{3}{|c|}{ Log populasi bakteri } \\
\hline & B. subtilis & $P$. kelompok fluorescens & S. marcescens \\
\hline \multicolumn{4}{|c|}{ - } \\
\hline 18 & $7.93 \mathrm{a}$ & $8.42 \mathrm{a}$ & $7.39 \mathrm{a}$ \\
\hline 21 & $4.25 \mathrm{~b}$ & $8.22 \mathrm{a}$ & $5.12 \mathrm{~b}$ \\
\hline 24 & $4.68 \mathrm{~b}$ & $4.77 \mathrm{~b}$ & $4.23 \mathrm{~b}$ \\
\hline
\end{tabular}

Keterangan : Angka yang diikuti huruf yang sama menunjukkan hasil yang tidak berbeda nyata menurut uji DMRT 5\%

Terdapat beberapa spesies bakteri yang dikenal sebagai bakteri rhizosfer (perakaran) atau rhizobakteri pemacu pertumbuhan tanaman (PGPR). Rhizobakteri pemacu pertumbuhan tanaman mampu mempengaruhi pertumbuhan tanaman dengan mekanisme yang berbeda baik secara langsung maupun tidak langsung, misalnya meningkatkan pelarutan mineral, fiksasi nitrogen, menekan patogen tular tanah dengan produksi siderofor, HCN dan antibiotik, produksi fitohormon serta meningkatkan toleransi tanaman terhadap cekaman lingkungan seperti kekeringan dan salinitas (Figueiredo et al. 2010). Rhizobakteri Bacillus spp., P. fluorescens dan Serratia sp. memiliki kemampuan dalam mensintesis hormon tumbuh, memfiksasi nitrogen atau melarutkan fosfat sehingga dapat meningkatkan viabilitas dan vigor bibit cabai (Sutariati dan Wahab 2012).

Nilai DB, IV, $\mathrm{K}_{\mathrm{CT}}$ dan BKKN perlakuan seed coating menggunakan bakteri lebih rendah dibandingkan kontrol. Hal tersebut diduga karena kondisi media tanam yang kurang sesuai (unfavourable) sehingga kinerja ketiga jenis bakteri tersebut kurang maksimal. Pertumbuhan dan aktivitas bakteri juga dipengaruhi oleh $\mathrm{pH}$ dan suhu lingkungan. Giyanto et al. (1999) menyatakan bahwa kecepatan membelah bakteri Pseudomonas fluorescens tercepat berkisar antara pH 6 dan 7 yang merupakan keadaan media yang cenderung netral. Sebagian besar bakteri ini juga mengalami pertumbuhan populasi maksimum pada suhu $25^{\circ} \mathrm{C}$.

Nilai IV dan BKKN mulai mengalami penurunan pada periode simpan 21 minggu, 
sedangkan $\mathrm{DB}$ dan $\mathrm{K}_{\mathrm{CT}}$ mulai turun pada periode simpan 24 minggu walaupun tidak berbeda nyata. Populasi bakteri juga menurun hingga periode simpan 24 minggu. Penurunan ini diduga karena kemampuan bakteri untuk bertahan di media (permukaan kulit benih cabai) semakin menurun. Bakteri tersebut mampu bertahan di permukaan kulit benih cabai hingga 24 minggu dapat disebabkan oleh endospora yang dibentuk, terutama pada Bacillus subtilis. Menurut Rindawana (2010), salah satu kelebihan B. subtilis ini karena dapat membentuk endospora sehingga mampu bertahan pada kondisi ekstrim seperti pada suhu $70-80{ }^{\circ} \mathrm{C}$ dan suhu minimum $10-15^{\circ} \mathrm{C}$. Hal tersebut membuat bakteri ini memiliki ketahanan yang sangat tinggi terhadap kondisi lingkungan yang kurang baik sebagai struktur bertahan.

Fitohormon yang umumnya mampu dihasilkan oleh PGPR adalah auksin Indole Acetic Acid (IAA). Auksin merupakan istilah umum untuk suatu kelompok senyawa yang mampu merangsang pemanjangan sel pucuk di daerah subapikal. Auksin biasanya merupakan asam dengan inti tidak jenuh atau derivatnya selain IAA ditemukan di urin, juga meluas di dunia tumbuhan, serta bakteri, cendawan dan ganggang ( Harjadi 2009).

Perlakuan tanpa coating (kontrol) dan coating menggunakan Bacillus subtilis, Pseudomonas kelompok fluorescens dan Serratia marcescens masih menunjukkan nilai viabilitas benih cabai yang baik hingga periode simpan 24 minggu. Benih kacang panjang yang diberi perlakuan coating menggunakan Methylobacterium spp. isolat TD-L2 setelah disimpan 12 minggu masih memiliki viabilitas yang tinggi, ditunjukkan oleh tolok ukur DB yaitu 90.3\% (Sari 2009). Hasil penelitian Yuningsih (2009) juga menunjukkan sampai dengan periode simpan 20 minggu, benih buncis tidak menunjukkan penurunan viabilitas secara nyata baik pada benih tanpa pelapis maupun dengan perlakuan dengan pelapis Methylobacterium spp. dengan nilai DB rata-rata $93 \%$.

\section{KESIMPULAN}

Perlakuan seed coating menggunakan
Bacillus subtilis, Pseudomonas kelompok
fluorescens dan Serratia marcescens maupun
perlakuan kontrol menunjukkan nilai viabilitas
yang masih tinggi pada benih cabai IPB C5
hingga akhir penyimpanan (periode simpan 24
minggu) yang ditunjukkan oleh nilai rata-rata
daya berkecambah, yaitu 77.3\%. Perlakuan
kontrol dan coating menggunakan bakteri menunjukkan nilai daya berkecambah, indeks vigor, kecepatan tumbuh dan bobot kering kecambah normal yang tidak berbeda nyata. Kadar air benih seluruh perlakuan seed coating menggunakan bakteri menunjukkan nilai yang lebih rendah, yaitu 3.84-3.94\% dibandingkan perlakuan kontrol $(6.31 \%)$. Ketiga bakteri yang digunakan sebagai pelapis masih dapat hidup sampai periode simpan 24 minggu dengan populasi $5.89 \times 10^{4} \mathrm{cfu} \mathrm{g}^{-1}$ untuk Pseudomonas kelompok fluorescens, $4.79 \times 10^{4} \mathrm{cfu} \mathrm{g}^{-1}$ untuk Bacillus subtilis dan $1.70 \times 10^{4} \mathrm{cfu}^{-1}$ untuk Serratia marcescens.

\section{DAFTAR PUSTAKA}

Agustiansyah. 2011. Perlakuan benih untuk perbaikan pertumbuhan tanaman, hasil dan mutu benih padi serta pengendalian penyakit hawar daun bakteri dan pengurangan penggunaan pupuk fosfat. disertasi. Bogor (ID): Institut Pertanian Bogor.

[BPS] Badan Pusat Statistik. 2012. Luas Panen, Produksi dan Produktivitas Cabai 20092011. [internet] [diunduh 2012 Okt 18] tersedia pada //www.bps.go.id/tab_sub/view.php?kat=3 $\&$ table $=1 \&$ daftar $=1 \&$ id_subyek $=55 \&$ nota $\mathrm{b}=26$.

[BPS] Badan Pusat Statistik. 2012. Produksi Sayuran di Indonesia [internet] [diunduh 2012 Okt 18] tersedia pada http://www.bps.go.id/tab_sub/view.php?kat $=3 \&$ tabel $=1 \&$ daftar $=1 \&$ id_subyek $=55 \&$ not $a b=26$.

Copeland, L.O., McDonald, M.B. 2001. Principles of Seed Science and Technology. 4th Edition. London (GB): Kluwer Academic Publisher.

Figueiredo MdVB, Seldin, L., de Araujo FF, Mariano RdLR. Plant Growth Promoting Rhizobacteria: Fundamentals and Applications. Maheswari DK, editor. Berlin (DE): Springer Verlag.doi:10.1007/978-3-642-13612-2-2.

Giyanto, Nawangsih, A.A., Mutaqin, K.H. 1999. Analisis keragaman molekuler Pseudomonas kelompok fluorescens dengan teknik RAPD (Random Amplified Polymorphic DNA) dan studi potensi antagonis terhadap Pseudomonas 
solanacearum pada tomat. [laporan Harjadi, S.S. 2009. Zat Pengatur Tumbuh. Jakarta (ID): Penebar Swadaya.

Kuswanto, H. 2007. Teknologi Pemrosesan, Pengemasan dan Penyimpanan Benih. Yogyakarta (ID): Penerbit Kanisius.

Rindawana, Lestari, E., Baharuddin, Lologau, B.A., Kuswinanti T. 2010. Keberadaan dan efektivitas bakteri antagonis pada rhizosfer kentang (Solanumtuberosum L.) sistem aeroponik terhadap Ralstonia solanacearum Smith secara in-vitro. Prosiding Seminar Ilmiah dan PertemuanTahunan PEI dan PFI 20 Komisariat Daerah Sulawesi Selatan.

Rubatzky, V.E., Yamaguchi, M. 1999. Sayuran Dunia 3: Prinsip, Produksi dan Gizi. Edisi kedua. Bandung (ID): Penerbit ITB.

Sari, P.E. 2009. Pengaruh komposisi bahan pelapis dan Methylobacterium spp. terhadap daya simpan benih dan vigor bibit kacang panjang (Vignasinensis L.). [skripsi]. Bogor (ID): Institut Pertanian Bogor.

Sumarni, N. 1996. Budidaya Tanaman Cabai Merah. Duriat AS, Hadisoeganda AWW, Soetarso TA, Purbaningrum L, editor. Jakarta (ID): Badan Penelitian dan Pengembangan Pertanian.

Suryaningsih, E., Sutarya, R., Duriat, A.S. 1996. Penyakit Tanaman Cabai Merah dan Pengendaliannya. Duriat AS, Hadisoeganda AWW, Soetarso TA, Purbaningrum L, editor. Jakarta (ID): Badan Penelitian dan Pengembangan Pertanian.

Sutariati, G.A.K., Widodo, Sudarsono, Ilyas, S. 2006a. Karakter fisiologis dan keefektifan penelitian]. Fakultas Pertanian IPB. isolat rizobakteri sebagai agens antagonis Colletotrichum capsici dan rizobakteri pemacu pertumbuhan tanaman cabai. Kultura 41 (1) : 28-34.

Sutariati, G.A.K, Widodo, Sudarsono, Ilyas S. 2006b. Pengaruh perlakuan Rizho-bakteri pemacu pertumbuhan tanaman terhadap viabilitas benih serta pertumbuhan bibit tanaman cabai. Bul. Agron. 34 (1) : 46-54.

Sutariati, G.A.K, Wahab A. 2012. Karakter fisiologis dan kemangkusan rizobakteri indigenus Sulawesi Tenggara sebagai pemacu pertumbuhan tanaman cabai. $J$. Hort. 22 (1) : 57-64.

Sutopo, L. 2004. Teknologi Benih. Jakarta (ID): PT Raja Grafindo Persada.

Wahyudi, A.T., Nawangsih, A.A., Saraswati, R., Yuniarti, E. 2008. Pseudomonas sp. rhizobakteria pemacu pertumbuhan tanaman yang berpotensi sebagai pengendali penyakit akar tanaman kedelai. [laporan hasil penelitian]. Lembaga Penelitian dan Pengabdian kepada Masyarakat IPB dan Sekretariat Badan Penelitian dan Pengembangan Pertanian.

Yukti, A.M. 2009. Efektivitas matriconditioning plus agens hayati dalam pengendalian patogen terbawa benih, peningkatan vigor dan hasil padi. thesis. Bogor (ID): Institup Pertanian Bogor.

Yuningsih, A.F.V. 2009. Pengaruh aplikasi Methylobacterium spp. terhadap viabilitas benih buncis (Phaseolusvulgaris L.) selama penyimpanan. skripsi. Bogor (ID): Institut Pertanian Bogor. 